DOI: 10.12731/2658-6649-2019-11-5-2-23-27

УДК 616.517: 612.017.1

\title{
ИММУНОЛОГИЧЕСКИЕ ПОКАЗАТЕЛИ У БОЛЬНЫХ ПСОРИАТИЧЕСКИМ АРТРИТОМ В ЗАВИСИМОСТИ ОТ СТЕПЕНИ ТЯЖЕСТИ ЗАБОЛЕВАНИЯ
}

Барило А.А., Смирнова С.В.

Актуальность изучения артропатической формы псориаза обусловлена прогрессирующим поражением суставов, нередко приводящим к инвалидизации, а также увеличением смертности больных. В статье приведень результаты сравнительного анализа иммунологических показателей в зависимости от степени тяжести псориатического артрита. Особенностями изменений иммунологических показателей в процессе прогрессирования патологии при псориатическом артрите среднетяжелой степени тяжести относительно легкой является сниженная кониентраиия ЦИК-СЗd в сыворотке крови.

Ключевые слова: псориаз; псориатический артрит; иммунопатогенез; циркулируюшие иммунные комплексы.

\section{IMMUNOLOGICAL PARAMETERS IN PSORIASIS DEPENDING ON THE DISEASE SEVERITY}

\section{Barilo A.A., Smirnova S.V.}

The relevance of studying the arthropathic form of psoriasis is due to progressive lesions of the joints, often leading to disability, as well as an increase in the mortality of patients. The article presents the results of a comparative analysis of immunological parameters, depending on the severity of psoriatic arthritis. The peculiarities of changes in immunological parameters in the course of progression of pathology in moderately severe psoriatic arthritis are relatively low is the reduced concentration of CIC-C3d in blood serum

Keywords: psoriasis; psoriatic arthritis; immunopathogenesis; circulating immune complexes.

\section{Введение}

Псориатический артрит (ПсА) является тяжелой формой псориатической болезни, которая характеризуется прогрессирующим необратимым 
поражением суставов и позвоночника [1]. Пристальное внимание к изучению артропатического псориаза обусловлена высокой частотой инвалидизации и повышением смертности больных [2]. В иммунопатогенеза заболевания при ПсА ключевая роль принадлежит активации Th1/Th17-лимфоцитов с последующей выработкой цитокинов, которые способствуют нарушению дифференцировки кератиноцитов эпидермиса и синовицитам [3, $4,5]$. Иммунопатологические механизмы в процессе прогрессирования ПсА окончательно не изучены, что указывает на необходимость проведения сравнительного анализа иммунологических показателей при псориатическом артрите в зависимости от степени тяжести заболевания.

\section{Цель исследования}

Провести сравнительный анализ иммунологических показателей в зависимости от степени тяжести псориатического артрита с целью выявления маркеров прогрессирования патологии.

\section{Материалы и методы}

В ходе исследования обследовано 60 больных ПсА от 18 до 66 лет

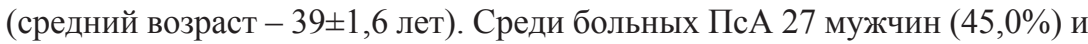
33 (55,0\%) женщины. В исследовании больные ПсА разделены на группы в зависимости от значения индекса PASI (Psoriasis Area and Severity Index): легкая степень тяжести - до 9,9 баллов включительно ( $\mathrm{n}=12$, группа 1$)$, средняя и тяжелая степень тяжести - от 10,0-30,0 баллов $(\mathrm{n}=48$, группа 2). Контрольная группа (n=103, группа 3) представлена практически здо-

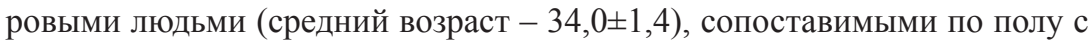
больными. Клеточное звено иммунитета определяли с использованием моноклональных антител к CD3, CD4, CD8, CD16, CD19 (TOO «Сорбент», г. Москва, Россия) с применением метода проточной цитофлуориметрии. Методом твердофазного иммуноферментного анализа оценивали концентрацию иммуноглобулинов (IgA, IgM, IgG), циркулирующих иммунных комплексов (ЦИК) в сыворотке крови. Для статистической обработки данных использовали программу Statistica 6,0. Полученные значения в тексте описываются в виде медианы, 25 и 75 квартилей (Me, Q25 - Q75). Статистически значимыми являлись различия при $\mathrm{p}<0,05$.

\section{Результаты и обсуждение}

Проведен анализ активности фагоцитоза при ПсА. При изучении фагоцитарной активности нейтрофилов во всех группах больных ПсА вы- 
явлено статистически значимо повышенное количество фагоцитов наряду со сниженным фагоцитарным числом в сравнении с контрольной группой: 40,0\% [38,0; 42,0], 42,5\% [35,0; 56,5] относительно $33,0 \%$ [29,0; 36,0], $\mathrm{p}_{1,3}=0,002, \mathrm{p}_{2,3}<0,007$ и $4,6[4,3 ; 5,3], 4,8[4,1 ; 5,3]$ относительно $5,6[4,9 ; 5,9]$, $\mathrm{p}_{1,3}=0,007, \mathrm{p}_{2,3}=0,001$, соответственно.

В результате проведенных нами исследований установлено, что в 1 и 2 группах больных ПсА относительное и абсолютное количество $\mathrm{CD} 16^{+}$-лимфоцитов в периферической крови статистически значимо выше в сравнении с контрольной группой: $8,0 \%$ [6,0; 10,0$], 9,5 \%$ $[7,0 ; 13,5]$ относительно $3,7 \%[2,3 ; 6,5], \mathrm{p}_{1,3}=0,005, \mathrm{p}_{2,3}<0,001$ и 140 кл/ мкл [121; 233], 164кл/мкл [122; 230] относительно 98 кл/мкл [37; 134], $\mathrm{p}_{1,3}=0,04, \mathrm{p}_{2,3}=0,003$.

При изучении показателей гуморального звена иммунитета в обеих группах больных ПсА определено, что концентрация IgA, IgM, IgG, ЦИКC1q в сыворотке крови статистически значимо ниже в сравнении с контролем. Установлено, что концентрация ЦИК-С $3 \mathrm{~d}$ в сыворотке крови в группах больных ПсА выше в сравнении с контрольной группой, причем у больных легкой степени тяжести ПсА концентрация ЦИК-С $3 \mathrm{~d}$ в сыворотке крови статистически значимо выше в сравнении с группой больных ПсА средней и тяжелой степени тяжести: 38,8 мгIgG/мл [27,7; 46,5] и 22,5 мг IgG/мл $[17,5 ; 35,3], \mathrm{p}_{1,2}=0,01$. Данные показатели, вероятно, являются следствием депонирования ЦИК-С $3 \mathrm{~d}$ в органах-мишенях при среднетяжелой форме артропатического псориаза.

\section{Заключение}

Таким образом, в ходе проведенного исследования установлены изменения следующих иммунологических показателей при артропатическом псориазе по отношению к контролю: повышенное количество в периферической крови $\mathrm{CD} 16^{+}$-лимфоцитов, фагоцитирующих нейтрофилов, сниженное фагоцитарное число, сниженная концентрация IgA, $\operatorname{IgM}, \operatorname{IgG}$, ЦИК-C1q в сыворотке крови. Маркером прогрессирования псориатического артрита является низкая концентрация ЦИК-С $3 \mathrm{~d}$ в сыворотке крови.

\section{Список литературы}

1. Смирнова С.В., Барило А.А., Смольникова М.В. Прогностическое значение клинических и анамнестических маркеров псориатического артрита. Клиническая дерматология и венерология. 2016; 15 (1):23-27. 
2. Смирнова С.В., Смольникова М.В., Барило А.А. Клинико-анамнестические критерии прогрессирования псориаза. Клиническая дерматология и венерология. 2016; 15 (2):9-15.

3. Барило А.А., Смирнова С.В., Смольникова М.В. Иммунологические показатели больных псориазом в различные возрастные периоды. Российский иммунологический журнал. 2017; 11 (20), 4: 680-681.

4. Барило А.А., Смирнова С.В., Смольникова М.В. Показатели иммунитета у больных псориатическим артритом в зависимости от возраста. Медицинская иммунология. 2019; 21 (1): 69-76.

5. Смирнова С.В., Смольникова М.В., Барило А.А. Концентрации IL-4, IL-6, IL-10, TNF $\alpha$ в сыворотке крови больных псориазом и псориатическим артритом. Цитокины и воспаление. 2015; 16 (3): 31-32.

\section{References}

1. Smirnova S.V., Barilo A.A., Smolnikova M.V. Prognosticheskoe znachenie klinicheskih i anamnesticheskih markerov psoriaticheskogo artrita [The prognostic value of clinical and anamnestic markers of psoriatic arthritis]. Klinicheskaya dermatologiya i venerologiya [Russian Journal of Clinical Dermatology and Venereology]. 2016; 15 (1):23-27.

2. Smirnova S.V., Smolnikova M.V., Barilo A.A. Kliniko-anamnesticheskie kriterii progressirovaniya psoriaza [Clinical and anamnestic criteria of the progression of psoriasis]. Klinicheskaya dermatologiya i venerologiya [Russian Journal of Clinical Dermatology and Venereology]. 2016; 15 (2):9-15.

3. Barilo A.A., Smirnova S.V., Smolnikova M.V. Immunologicheskie pokazateli bol'nyh psoriazom v razlichnye vozrastnye periody [Immunological indicators of patients with psoriasis in different age groups]. Rossijskij immunologicheskij zhurnal [Russian Journal of Immunology]. 2017; 11 (20), 4:680-681.

4. Barilo A.A., Smirnova S.V., Smolnikova M.V. Pokazateli immuniteta u bol'nyh psoriaticheskim artritom $\mathrm{v}$ zavisimosti ot vozrasta [The indicators of immunity in patients with psoriatic arthritis depending on the age]. Medicinskaya immunologiya [Medical Immunology]. 2019; 21 (1):69-76.

5. Smirnova S.V., Smolnikova M.V., Barilo A.A. Koncentracii IL-4, IL-6, IL-10, TNFa $\mathrm{v}$ syvorotke krovi bol'nyh psoriazom i psoriaticheskim artritom [The concentration of IL-4, IL-6, IL-10, TNF- $\alpha$ in the serum of psoriasis and psoriatic arthritis patients]. Citokiny i vospalenie [Cytokines and inflammation]. 2015; 16 (3):31-32.

\section{ДАННЫЕ ОБ АВТОРАХ}

Барило Анна Александровна, к.м.н., старший научный сотрудник лаборатории клинической патофизиологии 
Научно-исследовательский институт медииинских проблем Севера - обособленного подразделения ФИЦ КНЦ СО РАН

ул. Партизана Железняка, 32, г. Красноярск, 660022, Российская Федераиия

anntomsk@yandex.ru

Смирнова Светлана Витальевна, д.м.н., профессор, руководитель научного направления

Научно-исследовательский институт медицинских проблем Севера - обособленного подразделения ФИЦ КНЦ СО РАН

ул. Партизана Железняка, 32, г. Красноярск, 660022, Российская Федерациия

svetvita@mail.ru

\section{DATA ABOUT THE AUTHORS}

Barilo Anna Aleksandrovna, PhD, Researcher of the Clinical Pathophysiology Laboratory

Research Institute of Medical Problems of the North - a separate division of the FIC KSC SB RAS

3g, Partizan Zheleznyak, Krasnoyarsk, 660022, Russian Federation anntomsk@yandex.ru

Smirnova Svetlana Vital'evna, PhD, Professor, Head of the Scientific Direction

Research Institute of Medical Problems of the North - a separate division of the FIC KSC SB RAS

3g, Partizan Zheleznyak, Krasnoyarsk, 660022, Russian Federation svetvita@mail.ru 